\title{
The Emergence of the Paraprofessional in Academic Libraries: Perceptions and Realities
} Larry R. Oberg

\begin{abstract}
Several forces have contributed to a broad redistribution of tasks within the library workplace. Today, support staff accomplish much of the day-to-day work of the library and are routinely assigned tasks that a generation ago characterized the work of librarians. This redistribution of the library work load has created a new and unique class of library worker, the paraprofessional. It has also resulted in a significant overlap in the tasks performed by the two groups, for librarians have been curiously reluctant to give up many traditional aspects of their work that today can be performed satisfactorily by paraprofessionals. Task overlap has caused the role blurring that, in turn, creates resentment in the workplace and confuses our clientele who may not distinguish clearly between the two groups. The author cites data from his as yet unpublished national survey of the role, status, and working conditions of paraprofessionals. He concludes that a new model of librarianship is needed to define less ambiguously the role of paraprofessionals and librarians alike.
\end{abstract}

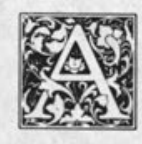

lthough support staff constitute the majority of all library workers, interest in them on the part of librarians has never been profound or sustained. This is curious because the post-World War II period has been characterized by the increasing utilization of support staff. Specifically, the past twenty or more years have witnessed far-reaching changes in the division of duties between the two groups. As academic librarians busied themselves with their newfound faculty status requirements of teaching, research, and governance, they became more and more dependent upon support staff. Librarians pressed support staff into service in new areas and assigned them tasks they no longer had the time to perform or had come to con- sider routine. As a result, many support staff, although certainly not all, are now regularly assigned duties that once characterized the work of librarians.

In addition to the new responsibilities faculty status has required of librarians, other forces have contributed to the rise or fall of many tasks within the library work hierarchy, for example,

- the increasing complexity of the tasks associated with the automation of library processes; ${ }^{1}$

- networking, ${ }^{2}$

- the shortage of qualified librarians and other problems related to their recruitment and retention; ${ }^{3}$

- declining or static budgets that require a higher level of efficiency in order to control costs;

- the direct substitution of support staff 
for librarians as a cost-saving measure; and

- an increasing emphasis on public service, and their evaluation.

The creation of new tasks and the redistribution of old ones have significantly upgraded the level of work performed by both support staff and librarians. ${ }^{4}$ Out of this process, a new class of library worker, the paraprofessional, has emerged. Paraprofessionals occupy the middle stratum of a three-tiered hierarchical staffing structure. Within this model, paraprofessionals are ranked below librarians, but above clerical employees.

The creation of new tasks and the redistribution of old ones have significantly upgraded the level of work performed by both support staff and librarians.

The phenomenon of paraprofessionalism is not without its parallels in other professions, for example, law and medicine, where the increased complexity of the fields has dictated the delegation of many complex tasks to support staff members. ${ }^{5}$ Today, the legitimacy of the library paraprofessional classification is generally recognized. However, the tasks assigned to these positions, the preparation required of the incumbents, and the reward structures vary widely.

\section{THE CHANGING LIBRARY WORKPLACE}

Paraprofessionals have liberated librarians from the need to perform any but their highest-level tasks. Librarians, however, have remained curiously reluctant to give up many aspects of library work that no longer need be performed by them, either failing to grasp the potential of paraprofessionals or perceiving them as a threat to their own positions. ${ }^{6}$ Consequently, the dramatic redistribution of the library work load has resulted in a wide zone of overlap in the tasks performed by the two groups. Task overlap characterizes today's workplace and blurs the distinc- tions between librarians and paraprofessionals. Role blurring angers paraprofessionals, who see themselves as doing what librarians do, but often for less money and always for less prestige.

In all fields, of course, professionals occasionally perform work characteristic of paraprofessionals just as paraprofessionals occasionally perform work characteristic of professionals. The problem lies in the degree to which this overlap in duties occurs and the precision with which the work of each group is defined. John Levett notes that some task overlap in libraries is to be expected. However, the width of the zone of overlap should concern us, he cautions, for herein lie "the seeds of conflict and issues of demarcation." The width of this zone, Levett continues, is determined by the relative maturity of the profession as measured in terms of social recognition and concessions granted. Levett concludes that one finds a wider zone of overlap in librarianship and social work than one does in medicine or architecture.

Today, few areas of library work are off limits to paraprofessionals, and they perform most of our traditional organizational and archival tasks. Paraprofessionals perform original as well as copy cataloging, search remote onlinedatabases, administer major functional areas within libraries and are regularly assigned to work at reference and information desks. $^{8}$

For the most part, these are tasks that only a few years ago librarians would not have permitted support staff to perform. In many libraries, particularly those in the larger publicly supported institutions, task overlap has been deliberately structured into the career ladders that order the responsibilities and the compensation of the two groups. In these libraries, higher-ranked paraprofessionals may be better rewarded than lower-ranked librarians. 9 In all libraries, however, task overlap, and the role blurring it creates, not only angers paraprofessionals but also confuses our clientele, who perceive librarians and paraprofessionals to be doing the same thing. This perception, whether true or 
false, is not a desirable one and can erode the quality of contacts between the library and its clientele. Larry R. Oberg, Mary Kay Schleiter, and Michael Van Houten argue, for example, that "librarians will need to communicate a clearer image of who they are and what it is they do. Otherwise, they perpetuate their isolation from institutional decisionmaking councils, ensure the continued underutilization of their abilities and knowledge, impoverish both client-librarian and client-collection contacts, and hinder their own efforts to become more involved in undergraduate education." 10

\section{PERCEPTIONS AND REALITIES}

In an environment where role blurring abounds, it is not surprising that tensions have developed between librarians and support staff. Allen B. Veaner states that in his experience, "the bitterest resentments and the greatest potential for explosive divisiveness are centered in this difficult personnel area." tional and administrative gulf that separates the two groups exacerbates the situation. The stage was set for conflict by 1971 , when the Association of College and Research Libraries adopted the Standards for Faculty Status for College and University Librarians. ${ }^{12}$ The Standards document gave renewed impetus to the efforts of academic librarians to upgrade themselves. It also mandated self-determination and "the maximum possible latitude" in fulfilling their responsibilities.

Faculty status and, since the 1960 s, a generalized movement away from the earlier authoritarian-based administrative models have given librarians more control over the content and organization of their work. With the adoption of the Standards, a flexible work schedule became both a necessity and a reality for academic librarians who were now required to teach, conduct research, publish, and participate in college and university governance. The Standards also mandated an academic form of governance for librarians, and they promptly organized themselves in a collegial manner parallel to that of their newfound teaching faculty colleagues. This more democratic or- ganizational model was then superimposed upon the library, a prototypical bureaucratic organization.

Of course, the bureaucratic format, with its compulsory forty-hour week, continues to dictate the schedules and organize the work lives of the support staff. Because the privileges of the collegial model were not extended beyond the professional ranks, two very dissimilar forms of governance came to coexist, often in uneasy juxtaposition, within most academic libraries. Veaner notes that although this bifurcate model grew out of "the structure of higher education itself," it nonetheless "impairs organizational unity and fosters adversarial relationships." 13

The animosity Veaner and others find in the library setting does not have an exact parallel in academic departments. Here, collegial governance appears to be a more comfortable fit, no doubt because members of the teaching faculty outnumber departmental secretaries who, in any case, are rarely in competition with them. ${ }^{14}$

Anecdotal evidence indicates that librarians and paraprofessionals often misunderstand each others' roles. In many libraries, the new duties assumed by librarians and the reasons why they require collegial organizational models and flexible work schedules were never adequately explained to support staff. The seeming inability of librarians to state more precisely what it is that they do has contributed to the role blurring and resentment that exist today.

Often, paraprofessionals appear not to comprehend the scope of the responsibilities that librarians are expected to assume and perceive themselves to be doing equivalent work. Librarians may misconstrue the resentment that the support staff feel, treat them patronizingly, and even doubt the extent of their commitment to the library. Such attitudes on the part of librarians are, of course, counterproductive and become self-fulfilling prophesies that insure low self-esteem in paraprofessionals and prevent them from demonstrating a higher level of institutional and professional commitment. 
The approach taken by librarians to these problems has been shortsighted, and we have failed to exercise leadership in this important area. Despite the real structural differences that exist, many librarians tend to ignore or minimize the distinctions between the two groups. This understandable desire to be democratic and not elitist is in conflict, however, with our traditional demand for two fundamentally different types of library workersthose who at least until recently were assigned only routine process-oriented work, and those who are responsible for the planning, decision making, and other programmatic aspects of the library. Failure to deal explicitly with the stratification that is inherent, not only in academic libraries, but also in the academy generally, results from our traditional unwillingness to come to terms with the problems of personnel utilization and contributes to the role blurring that characterizes our libraries today.

\section{THE LITERATURE}

Until quite recently, the literature that describes and analyzes the role, status, and working conditions of paraprofessionals within librarianship could at best be described as thin. With few exceptions, we have skirted these troublesome personnel issues. At the national level, authors have focused upon the more peripheral concerns of training and outcomes of support staff utilization in nontraditional roles, for example, at the reference desk or performing complex cataloging tasks. This particular literature betrays a remarkable degree of apprehension on the part of librarians about the advisability of assigning to paraprofessionals tasks that were previously performed by professionals. At the state and regional levels, the literature has been anecdotal, often condescending, and has added little to our understanding of the problems that beset paraprofessionals. A few exceptions, however, dot this rather bleak landscape.

In 1923, Charles C. Williamson urged the differentiation of professional from clerical tasks in his Carnegie Corporation-sponsored report, Training for $\mathrm{Li}$ - brary Service. ${ }^{15}$ Although most of the Williamson report addressed the specifics of curriculum reform, the author strongly recommended that library work be performed by two different classes of employees, professional and clerical, and that each group be supported by its own distinct training program. In his history of library technician training programs in the United States and Canada, Charles Holborn Held notes with some irony that Williamson's educational solution had to wait forty-six years to be endorsed by the American Library Association. ${ }^{16}$ Despite the associational sanction it finally received, the concept has not found widespread acceptance at the grass-roots level. ${ }^{17}$

\section{The approach taken by librarians to these problems has been shortsighted, and we have failed to exercise leadership in this important area.}

Orvin Lee Shiflett, in his highly readable 1981 monograph Origins of American Academic Librarianship, defines the basic forces and events that have shaped academic librarianship. ${ }^{18}$ Library training in the pre-Williamson era, generally referred to as the Dewey to Williamson period, has been described by Sarah K. Vann in her monograph, Training for Librarianship before 1923. ${ }^{19}$ In 1979, Charles W. Evans traced the history of support staff and the evolution of paraprofessionals in a review article entitled "Evolution of Paraprofessional Library Employees." 20

A brief review of library support staff history, "In the Beginning, There Was Support Staff ... ," by Edward B. Martinez, appeared in 1989 in the first issue of the support staff journal Library Mosaics. ${ }^{21}$ The development of library paraprofessionals as a class has been sketched by Charlotte Mugnier in her 1980 monograph, The Paraprofessional and the Professional Job Structure. ${ }^{22}$ Mugnier notes a growing acceptance of the concept of paraprofessionalism within most 
service professions. Within librarianship, she suggests, acceptance is implicit in the promulgation of the American Library Association's 1970 policy statement, Library Education and Personnel Utilization (LEPU). ${ }^{23}$

Among those rare librarians who have looked squarely at the problems of paraprofessionals is Richard M. Dougherty, who as early as 1977 pointed to "a growing rift in the relations between professionals and other library staff." A University of California, Berkeley veteran of the social upheaval of the early 1970 s, Dougherty warned that library assistants were becoming increasingly dissatisfied with their status as they assumed tasks relinquished by librarians. These higher-level responsibilities, he remarked, "too often have not been accompanied by commensurate rewards." ${ }^{24}$

In the early 1980s, Veaner traced a history of rapid change in academic libraries over the prior two decades. The role confusion that emerged during this tumultuous period, he notes, gave rise to the widespread "perception that two categories of employees are performing widely overlapping functions, seemingly at the same level, but in different employee series with different pay scales and different [perquisites]." Many librarians, Veaner notes, have contributed to this perception by failing to recognize "that changing times have drained away the professional challenge that once inhered in certain tasks." 25

At least two empirical studies support Dougherty and Veaner's somewhat pessimistic assessments. Although job satisfaction surveys have been relatively common in the library literature, only a few have included support staff. In 1983, Beverly P. Lynch and Jo Ann Verdin reported data they had collected in 19711972 in three university libraries. They found "significant differences [in the levels of satisfaction] between the occupational groups," with "the professional librarians reporting higher satisfaction than the other members of the staff." ${ }^{26}$ In a 1987 replication of their study, the authors concluded that these differences have held steady over time, and that "the professional group continues to report higher [levels of] job satisfaction than other staff members." 27

More recently, Patricia A. Kreitz and Annegret Ogden surveyed job responsibilities and job satisfaction among professionals and support staff at the nine-campus University of California system. In response to their question, "In general how satisfied are you with your present job?" the authors found that 76 percent of the librarians checked the two highest categories on a 5-point scale, while only 50 percent of the library assistants did. Kreitz and Ogden also found significant blurring of the roles of librarians and library assistants and reported "a major overlap of responsibilities in the area of creating bibliographic access, small but provocative overlaps in the areas of collection development and public services, and a strong division of responsibilities in management-related activities." 28

\section{NEW INITIATIVES}

Fortunately, librarians' general lack of attention to paraprofessional concerns has begun to change. There has been a small but perceptible increase in the number of research-based articles to appear in the literature. Library Mosaics, a new journal devoted exclusively to support staff issues, began publishing in 1989; in 1990, a highly successful national conference for support staff entitled Working in Libraries was held by the continuing education division of the School of Library and Information Studies at the University of Wisconsin, Madison, and then repeated because of high demand. In recent years, significant growth has occurred in the number, strength, and activities of paraprofessional sections within state and regional library associations; and at least two major projects intended to review support staff concerns have been initiated at the national level.

In 1990, the American Library Association's Standing Committee on Library Education (SCOLE) and the Office for Library Personnel Resources' (OLPR) Advisory Committee received a World 
Book-ALA Goal Award to complete a one-year project on the condition of support staff. Project leaders presented a preconference program on paraprofessionals at the 1991 Annual Conference of the American Library Association, conducted focus group interviews with support staff and librarians, and plan to publish a collection of commissioned articles on library support staff issues. ${ }^{29}$

Appointed in 1988, the Association of College and Research Libraries' Task Force on Paraprofessionals was charged with reviewing the academic preparation of paraprofessionals, examining the career paths available to them, and recommending an appropriate role for them within the ACRL. In December 1990, the task force, chaired by Sheila Creth of the University of Iowa, submitted its final report in which it recommended increased participation of paraprofessionals within the association..$^{30}$

In her final recommendation as executive director of the Association of College and Research Libraries, JoAn Segal proposed that the ACRL add a new category of membership to accommodate paraprofessionals. A special membership category, Segal notes, "would strengthen relations in the workplace, serve as a recruitment tool for entry into the professional ranks, and indicate our willingness to provide educational and other activities for an important segment of the academic library work force." ${ }^{11}$

Since its inception in 1967, the Council on Library/Media Technicians (COLT) has sought to improve the working conditions and defend the interests of library support staff. An American Library Association-affiliated membership organization, COLT provides a forum for the discussion of support staff issues and the promotion of support staff goals. COLT's annual conference is held in conjunction with the ALA's summer conference.

\section{WHAT'S IN A NAME?}

Paraprofessional position and employment series titles have proliferated at the local level. Standardization has not occurred and terminology varies widely in usage and meaning. My and Mark E.
Mentges' as yet unpublished 1990 national survey of the role, status, and working conditions of paraprofessionals confirms the widespread impression that there is significant concern about, but little agreement on, nomenclature. The responses of the library directors surveyed make it clear that the term paraprofessional is a highly charged one. A number of these directors responded that they simply do not like it. Others reported that it is considered demeaning by some staff who prefer such terms as support professional or even librarian. Still others noted that they employ only clerical workers, none of whom they felt qualify as paraprofessionals by the definition provided.

My survey definition of paraprofessionals suggested that these positions have entrance-level requirements that are distinctly different from those of librarians, that incumbents are assigned high-level support responsibilities, and that they commonly perform their duties with some supervision by a librarian. ${ }^{32}$ This slight attempt at definition, however, is not adequate to allow us to distinguish with confidence between paraprofessionals and clerical employees or between paraprofessionals and nonlibrarian professionals. Indeed, the lines that separate paraprofessionals from these other categories are as indistinct as those that separate them from librarians.

Associational definitions of paraprofessionals, those of the American Library Association and the American National Standards Institute (ANSI), for example, are weak at best and stand in need of revision. ${ }^{33}$ At the local level, titles, such as acquisitions clerk and reference assistant, may not accurately reflect the scope of the responsibilities that these positions demand and risk offending the incumbents.

Anecdotal evidence suggests that some paraprofessionals and even a few librarians tend to deny the existence of clerical positions and consider all fulltime support staff to be paraprofessionals. In some libraries, this perception results from a failure to distinguish between the capabilities of exceptional in- 
dividuals and objective job requirements. In others, it accurately reflects the informal patterns of use made of these support staff. In small libraries, where support staff may be called upon to perform a wide range of duties, the lines of demarcation frequently tend to blur.

In all cases, however, paraprofessionals are a subset of the broader universe of support staff. The term is misleading when, as is often the case, it is applied without distinction to all classifications of library employees who are not librarians. Secretaries, typists, bookkeepers, and others whose jobs require only clerical or office-related skills are not paraprofessionals. Student library employees; van drivers; mailroom workers; audiovisual technicians; or nonlibrarian professionals, for example, library business and personnel officers, accountants, archivists, systems analysts, and programmers, do not fit the current definitions of paraprofessional either. Many of the new tasks that automation is creating in libraries, for example, data input and the management of CD-ROM services and microcomputer laboratories, remain to be classified within the work hierarchy.

\section{THE CONDITION OF PARAPROFESSIONALS}

Despite the profound nature of the changes that have occurred in the library workplace, librarians have not thoroughly analyzed the impact of these changes upon the individuals affected or upon the profession itself. In fact, it is fair to say that the profession has yet to come to grips with the emergence of paraprofessionals as a distinct class of library worker. The accelerating movement toward the use of support staff to perform complex library tasks has come about at the grass-roots level, to a large extent unaffected by the few national policy statements that define support staff activities and educational qualifications.

Many problems related to paraprofessional qualifications, utilization, classification, continuing education, and even nomenclature remain to be resolved. The Library Education and Personnel Utilization document, the most recent
ALA Council-approved policy statement on library staffing patterns, formal educational requirements, and continuing education dates from 1970, although it is now under revision. In addition to defining professional positions, LEPU currently recommends three categories of support staff: library associates, library technical assistants, and clerks. The document delineates the training, educational requirements, and some duties appropriate to each level. Although the term is not used in the document, LEPU nonetheless anticipates and codifies library paraprofessionalism. LEPU was a breakthrough document for its time, but the model employment categories and the prerequisites that it proposes have not been widely accepted or implemented.

The only other American Library Association Council-approved policy statement that addresses the education of paraprofessionals is the Criteria for Programs to Prepare Library/Media Technical Assistants document. Published in 1969 and revised in 1979, the Criteria document establishes curricular standards for twoyear educational programs for paraprofessionals. ${ }^{34}$ In the field, however, the educational qualifications that are required of paraprofessionals vary widely from institution to institution and reveal a signal lack of standardization. Ad hoc standards are set in the workplace and equivalent tasks are performed by incumbents with widely varying backgrounds.

My survey reveals that 98 percent of all academic libraries in the United States require a high school degree of some or all of the paraprofessionals in their employ; 62 percent, an associate degree (a figure that rises to 78 percent at the two-year schools that traditionally grant them); and 64 percent, a bachelor's degree. Nine percent of all responding libraries require a graduate degree of some, but not all, paraprofessionals. Still, most of these libraries get more than they ask for: 65 percent report employing one or more paraprofessionals who hold a degree higher than that required for their jobs.

The recent spate of interest in paraprofessionals and, by extension, support 
staff generally, has not yet translated into significant improvements in their condition. Despite the shift of many high-level tasks to paraprofessionals, they may not be receiving the training, support, and compensation they need to get the job done. For example, 90 percent of my respondents offer paraprofessionals released time to attend local and regional conferences and workshops, but only 32 percent extend this incentive for attendance at national meetings. Eightyone percent of the responding libraries offer financial support for attendance at local and regional meetings, but that figure drops to 24 percent for attendance at national meetings. Rush G. Miller points out that "one of the greatest impediments to support staff development is the lack of funding for travel." Funding, he insists, is vital for the success of any staff development program. ${ }^{35}$

Compensation for paraprofessionals varies greatly by type of library and geographical location. In many libraries, adequate compensation is inhibited by inappropriate salary comparisons that continue to be made between increasingly complex paraprofessional positions and totally unrelated jobs in physical plant, food services, business offices, and academic departments. ${ }^{36}$ These traditional linkages are no longer useful and can severely depress paraprofessional salaries and status. It appears that librarians have not done a good job of making campus administrators and personnel officers aware of the magnitude of the changes in the job descriptions of library support staff.

My survey indicates that only 45 percent of the academic libraries in the United States provide paraprofessionals with a ranked classification system, or career ladder, that ensures the possibility of position reclassification. This figure rises to 87 percent at the large Association of Research Libraries institutions, but drops to 23 percent in the smaller liberal arts college libraries.

In summary, the educational requirements for paraprofessionals vary widely from institution to institution and often bear little resemblance to the LEPU standards. Staff development programs and continuing education opportunities are spotty and funding is inadequate. Our seeming inability to distinguish between the capabilities of individuals and objective position requirements confuses the issue. The problems of role definition and nomenclature are national in scope and result from the lack of a consensus on who paraprofessionals are and what it is that they should be doing. Our inability to define these groups more precisely hinders our research by rendering the statistics that we generate less than fully comparable. Perhaps most importantly, librarians have simply failed to demonstrate vision or exercise leadership in these areas.

\section{Librarians have not done a good job of making campus administrators and personnel officers aware of the magnitude of the changes in the job descriptions of library support staff.}

The following section contains some suggestions for dealing with these problems, but it is not an exhaustive attempt to resolve all of them. It is offered only as a catalyst to discussion.

\section{WHAT NEEDS TO BE DONE?}

Some of the apprehension librarians used to feel about the emergence of paraprofessionals has dissipated, and today we are less likely to perceive them as a threat. Most librarians understand that in an environment characterized by rapid change, it is the continued performance of the more routine tasks, not their delegation to support staff, that depresses the status of professionals.

Michael Gorman reminds us that "the number of tasks deemed to be professional should not exceed the number of tasks which need to be performed by professionals." As a rule of thumb, Gorman suggests, "no professional should do a task which can be performed by a paraprofessional, no paraprofessional should do a task which can be performed by a clerical staff member, [and] no 
human being should do a task which can be performed by a machine." 37

Still, librarians have not achieved a clean fit between the paraprofessional and professional groups that proliferate within the library workplace. Gorman warns that "we have to reach a point at which we can affirm the value of professionalism and the value of contributions made by paraprofessionals and clerical staff without confusing their respective roles." 38

Herbert S. White has proposed a model for the integration of librarians and nonlibrarian professionals. In White's model, the librarians remain firmly in control of the library and information processes, but coexist with the other professionals to whom they accord equivalent rights and the compensation professionals expect and deserve. "The point," White states, "has always been that there could easily be other professional skills represented in large and complex organizations." ${ }^{39}$ Because the nature of paraprofessional positions has changed as incumbents have assumed increasingly complex tasks, White's model could be expanded to include these new tasks.

In the final analysis, what do paraprofessionals want? Most likely, I think, respect, trust, collegiality, just compensation, and a future-in short, a career, and not just a job. As librarians, we should grant them that. A library sustains an enormous waste of potential and talent when paraprofessionals are kept down, undertrained, and denied responsibility and respect. In my opinion, the time is long past due for librarians to accept paraprofessionals as colleagues in more than name only.

Paraprofessionals should receive the systematic training, staff development, and continuing education opportunities that are needed to ensure the conditions required for their success. The educational prerequisites these jobs demand must be reviewed closely, and realistic enforceable standards established. Most difficult of all, funding for attendance at state, regional, and even national meetings will need to be found and incumbents encouraged to attend. Mark E. Mentges notes that "if the recent interest expressed by paraprofessionals in letters to national magazines such as Library Journal and American Libraries are [is] any indication, large numbers are now thinking and acting on a national level." ${ }^{40}$ At the national level, librarians must place a high priority upon paraprofessional concerns in their strategic planning councils and on their national research agendas.

Of course, paraprofessionals and librarians alike should assume increased responsibility for upgrading their own qualifications. The challenge for librarians, who are often perceived by paraprofessionals to be doing less than professional-level work, is to give up their attachment to the lower-level tasks that they in fact need perform only occasionally and redefine their positions in terms of their most complex and challenging professional responsibilities. ${ }^{41}$

\section{What do paraprofessionals want? Most likely, I think, respect, trust, collegiality, just compensation, and a future-in short, a career, and not just a job.}

In a discussion of the qualifications required of catalogers, Sheila S. Intner challenges librarians "to [wake] up to the fact that they trivialize their field if they are satisfied doing jobs that should belong to well trained paraprofessionals." Were we to insist that these tasks be performed by properly trained paraprofessionals, she notes, librarians would "free [themselves] to do more challenging, interesting, and important work." $^{\prime 2}$ Because certification does not exist in librarianship, librarians who persist in performing tasks that can be performed satisfactorily by less highly qualified staff are protected as they create role confusion for our clientele and embarrassment to the profession.

The challenge for paraprofessionals is to cast their gaze beyond the internal procedures that have traditionally preoccupied them and make the service role and mission of the library their primary 
point of reference. They should accept that not all support staff, not even all those who are doing library-specific tasks, qualify as paraprofessionals. Paraprofessionals also need to gain a clearer understanding of the librarians' role and the importance of their research, teaching, governance, planning, and administrative responsibilities. Finally, they must stop blaming librarians for their own ills. Miller suggests that this attitude "is no more likely to bridge the chasm between [the two groups] than is [the librarians'] insistence of superiority." ${ }^{\prime \prime 3}$ In sum, many ingrained habits of librarians and paraprofessionals alike must change.

The empowerment of paraprofessionals should not be perceived as a threat to professional positions. Many tasks, of course, continue to be driven downward in the work hierarchy by technology, networking, resource sharing, and the other changes that are altering the information environment. These same forces, however, drive yet other tasks upward and create exciting new opportunities for librarians and all information professionals.

In order to meet these challenges effectively, librarians must define their role less ambiguously. When they clarify their own ambivalent status, they will have gone a long way toward resolving the problems that cloud the role and status of the paraprofessional. Indeed, how can we as librarians expect to help paraprofessionals decide who they are if we cannot first decide who we are?

\section{THE PROBLEM OF DEFINITION}

Over one hundred years have passed since Dewey rather optimistically proclaimed us a profession, ${ }^{44}$ yet we are still without an adequate definition of a librarian or a comprehensive model of librarianship. In 1933, Pierce Butler urged the scientific method upon the librarian, whom he found to be "strangely uninterested in the theoretical aspects of his profession," an isolated figure who "stands alone in the simplicity of his pragmatism. ${ }^{\prime \prime 5}$ In truth, librarians today remain as unsure of what librarianship is or ought to be as they were nearly sixty years ago when Butler implored them to look beyond process and toward function.

Almost twenty years after the ACRL adopted the Standards for Faculty Status for Academic Librarians document, faculty status as the desired condition of all academic librarians has yet to be accepted fully by the membership. A range of alternative status models proliferates on our campuses, and librarians (or, more likely, the administrators to whom they report) choose with impunity between faculty, academic, administrative, professional, and even librarian variants. ${ }^{46}$

\section{Paraprofessionals should receive the systematic training, staff devel- opment, and continuing education opportunities that are needed to ensure the conditions required for their success.}

For decades, librarians have attempted to sort the professional wheat from the paraprofessional chaff by compiling lists of the tasks that putatively define each category. In most respects, this has been a singularly unrewarding exercise. Its one great virtue, however, has been to demonstrate that librarianship is more than the sum of its parts. Still, a new theoretical model of the profession, a lens through which librarians can view, organize, and evaluate practice, has yet to emerge. When it does, however, this new model will surely see librarians concentrating more of their time upon the most professional aspects of their work and less upon the repetitive tasks. Almost certainly, it will see librarians accord paraprofessionals considerably greater responsibility for the day-to-day running of the library.

In 1982, Veaner challenged the profession to decide between two mutually exclusive concepts of librarianship, concepts he terms continuous and discontinuous. ${ }^{47}$ Under the terms of his continuous model, no sharp breaks occur between the various levels of work or the categories of workers required to perform them. The tasks required of this model, no matter 
how difficult, complex, or challenging, may be learned by incumbents through apprenticeship, and the individual worker advances on a potentially unlimited continuum. If continuity characterizes librarianship, Veaner warns, we must accept that it is a craft and not a profession.

Veaner contends, however, that librarianship is in fact characterized by discontinuity. He maintains that two fundamentally different types of work exist, each requiring its own separate and distinct group of workers. One group functions in a support capacity and is characterized by the performance of process-oriented tasks, i.e., the craft work of libraries. The other group requires graduatelevel training and is characterized by programmatic responsibilities and theabstract, intellectual nature of the work performed, i.e., the professional work of libraries.

In Veaner's discontinuous model, the librarian not only assumes responsibility for research, teaching, governance, collection development, bibliographic control, and direct patron aid, but also for planning, design, analysis, evaluation, problem solving, and administration. In brief, the librarian is responsible for creating the conditions that ensure the success of the library.
The time is at hand to decide between these two fundamentally opposed concepts of librarianship. If librarians continue to avoid endorsing one or the other, we cannot say that we have not been warned. Veaner tells us that "the problem of personnel utilization can be postulated as a fundamental question of librarianship" and, he cautions, "the answer may have profound implications for the status of librarians, for graduate education in library science, for the academic institution's budget, for collective bargaining, and potentially for class action litigation in the area of equal pay for equal work." 48

The problem of role definition and articulation is at the heart of our predicament. The inability of librarians to define their own role less ambiguously inhibits us from describing paraprofessionals more precisely, from explaining ourselves to clients who fail increasingly to distinguish between the two groups, and from exercising leadership in this important arena. The emergence of the paraprofessional as an active, vital force in our libraries compounds librarians' ageold identity crisis and challenges us to resolve at last the problem of our status.

\section{REFERENCES AND NOTES}

1. The fact that "the productivity tools which automation has made possible have reduced the skill level required to do certain types of library work," is noted in "Changing Staffing Patterns in Academic Libraries," Library Issues: Briefings for Faculty and Administrators 7:2 (Sept. 1986).

2. Patricia Glass Schuman notes that "networking does tend to move tasks formerly considered professional downward-particularly in the areas of circulation, cataloging, acquisitions, and interlibrary loan." See Schuman, "Library Networks: A Means, Not an End," Library Journal 112:34 (Feb. 1, 1987). The fact that "the standardization which the national cataloging systems has made possible permits many libraries to use paraprofessional and clerical staff to handle work which formerly required the skills of a professional catalog librarian," is noted in "Changing Staffing Patterns," p.2.

3. Kathleen M. Heim, "Librarians for the New Millennium," in Librarians for the New Millennium, ed. William E. Moen and Kathleen M. Heim (Chicago: Office for Library Personnel Resources, American Library Association, 1988), p.1-10.

4. In a discussion of the "technological imperative," Allen B. Veaner suggests that the application of a technology drives very complex, but routine, mental work downward in the hierarchy of tasks. No longer essential to the performance of these tasks, professionals cease to be production workers. Their work then becomes abstract and predominately intellectual, comprehending new and challenging responsibilities. See Veaner, "Librarians: The Next Generation," Library Journal 109:624 (Apr. 1, 1984).

5. For a comparison of the status of library paraprofessionals with their counterparts in law and medicine, see Kathleen M. Heim and Debbie Wolcott, with the assistance of 
Ed McCormack, "Staff Utilization in Libraries: The Historical and Environmental Context for Renewed Attention to Education, Role Definition, and Articulation with Special Consideration of Medicine and Law," Louisiana Library Association Bulletin 52:149-57 (Spring 1990). See also John Levett, "Paraprofessional Workers in Four Fields: A Comparative Study," The Australian Library Journal 30:47-54 (May 1981).

6. Ralph M. Edwards points out that "many people who are supposed to be functioning as librarians have always avoided professional responsibility by immersing themselves in routine clerical work. Uninformed management attitudes and techniques in libraries have frequently abetted this dereliction of professional function." See Ralph M. Edwards, "The Management of Libraries and the Professional Functions of Librarians," Library Quarterly 45:150 (Apr. 1975).

7. Levett, "Paraprofessional Workers in Four Fields," p.48.

8. In 1990, Mark E. Mentges (University of California, Berkeley) and I conducted an as yet unpublished survey of all ARL reference libraries and a random sample of almost 400 Carnegie classification libraries nationally. Of the responding Carnegie classification libraries, 61 percent regularly assign to paraprofessionals Library of Congress input copy cataloging and approximately 20 percent assign original cataloging, including description, subject analysis, and classification. Online database searching is regularly performed by paraprofessionals in 21 percent of these libraries; 46 percent assign substantial administrative responsibility to paraprofessionals in circulation, 30 percent in interlibrary loan, 33 percent in periodicals, 27 percent in acquisitions, and 22 percent in cataloging. Sixty-six percent of these libraries regularly schedule paraprofessionals to work at the reference/information desks.

9. Thirty percent of the library directors in all libraries responding to my survey report that they have at least some paraprofessionals in their employ who earn a salary comparable to or higher than entry-level librarians. This figure rises to 87 percent in large research institutions and declines to 14 percent in liberal arts colleges.

10. In a survey of Albion College faculty, Oberg, Schleiter, and Van Houten found that "77\% [of their respondents] could not identify by name all five Albion College librarians although the campus community is quite small and the nature of professional employment clearly outlined on the questionnaire. Further, $40 \%$ identified as librarians one or more members of the support staff. These were most often staff with whom they have frequent contact-circulation, interlibrary loan, and periodicals department employees, for example." Larry R. Oberg, Mary Kay Schleiter, and Michael Van Houten, "Faculty Perceptions of Librarians at Albion College: Status, Role, Contribution, and Contacts," College \& Research Libraries 50:225 (Mar. 1989). In a survey of the image of the librarian, Joan C. Durrance suggests that "the profession that fails to distinguish between librarians and other staff (who have not had the benefit of a professional education) is culpable for any opinions that the public may form about librarians' ability." Durrance, "Librarians: The Invisible Professionals," in The Bowker Annual Library and Book Trade Almanac, 35th ed., (New York: Bowker, 1990), p.96.

11. Allen B. Veaner, personal communication, Sept. 28, 1990.

12. Association of College and Research Libraries, Academic Status Committee, "Standards for Faculty Status for College and University Librarians," in Academic Status: Statements and Resources (Chicago: American Library Association, 1988), p.9-10.

13. Allen B. Veaner, Academic Librarianship in a Transformational Age: Program, Politics, and Personnel (Boston: Hall, 1990), p.439.

14. Miller notes that "Secretaries and faculty members may have conflicts, but the secretary would not dream of aspiring to be a faculty member, nor would the faculty see a rivalry in the relationship. In other words, their respective roles are clearly delineated and few inherent conflicts arise." Rush G. Miller, "Support Staffs in Academic Libraries: The Dilemma and the Challenge," Journal of Educational Media and Library Sciences 25:357 (1988).

15. The two Charles $C$. Williamson reports, the original unpublished manuscript and the published report, have been reissued as Training for Library Work (1921) and Training for Library Service (1923), (Metuchen, N.J.: Scarecrow, 1971), 2v.

16. Charles Holborn Held, The Status of Library Technicians in the United States: A Dissertation (Detroit: Wayne State University, Graduate Division, 1969). It was not until 1969 that 
the American Library Association published its Criteria for Programs to Prepare Library Technical Assistants: Statement of Policy.

17. For a discussion of the postsecondary educational programs for library technicians, see Ian M. Johnson, "The Development of Library Technicians: A Review of Experience in Selected Countries," International Federation of Library Associations and Institutions (IFLA) General Conference, 1990, Booklet 3. (The Hague: IFLA, 1990; Bethesda, Md.: ERIC Document Reproduction Service, ED 329 284, 1991), p. 53-61.

18. Orvin Lee Shiflett, Origins of American Academic Librarianship (Norwood, N.J.: Ablex, 1982).

19. Sarah K. Vann, Training for Librarianship before 1923 (Chicago: American Library Association, 1961).

20. Charles W. Evans, "The Evolution of Paraprofessional Library Employees" in Advances in Librarianship 99:64-97 (New York: Academic, 1979).

21. Edward B. Martinez, "In the Beginning, There Was Support Staff," Library Mosaics 1:6-8 (Sept./Oct. 1989).

22. Charlotte Mugnier, The Paraprofessional and the Professional Job Structure (Chicago: American Library Association, 1980).

23. American Library Association, Library Education and Personnel Utilization: A Statement of Policy by the Council of the American Library Association, June 30, 1970 (Chicago, 1976). The LEPU document, originally entitled Library Education and Manpower, was revised and edited in 1976 by the Office for Library Personnel Resources' (OLPR) Advisory Committee to remove sexist terminology.

24. Richard M. Dougherty, "Personnel Needs for Librarianship's Uncertain Future," in Herbert Poole, ed., Academic Libraries by the Year 2000: Essays Honoring Jerrold Orne (New York: Bowker, 1977), p.112.

25. Allen B. Veaner, "Continuity or Discontinuity-A Persistent Personnel Issue in Academic Librarianship," Advances in Library Administration \& Organization 1:3 (1982). In the original published source, the author notes, the word perquisites was inadvertently transposed into prerequisites.

26. Beverly P. Lynch and Jo Ann Verdin, "Job Satisfaction in Libraries: Relationships of the Work Itself, Age, Sex, Occupational Group, Tenure, Supervisory Level, Career Commitment, and Library Department," Library Quarterly 53:442 (Oct. 1983).

27. Beverly P. Lynch and Jo Ann Verdin, "Job Satisfaction in Libraries: A Replication," Library Quarterly 57:199 (Apr. 1987).

28. Patricia A. Kreitz and Annegret Ogden, "Job Responsibilities and Job Satisfaction at the University of California Libraries," College \& Research Libraries 51:307 (July 1990).

29. "Research and Action Agenda for Support Professionals in Libraries," Application for World Book-ALA Goal Awards, unpublished manuscript, 1990.

30. American Library Association, Public Information Office, ACRL Task Force Recommends Increased Paraprofessional Participation (Chicago: American Library Association, 1990).

31. Association of College and Research Libraries, Academic Librarians: Partners in Higher Education: The 1989-90 Annual Report (Chicago: American Library Association, 1990), p.9.

32. The definition of paraprofessionals that I wrote for my 1990 survey-based to a large extent upon ALA and IPEDS definitions-follows: "The term paraprofessional designates library positions with entrance-level requirements that are distinctly different from those of librarians. Paraprofessionals are assigned high-level support responsibilities in positions whose tasks are specific to libraries. They commonly perform their duties with some supervision by a librarian. The term is often applied to personnel classified as library assistants, associates, technicians, and technical assistants. Examples of paraprofessional position titles include: head of circulation, interlibrary loan assistant, acquisitions coordinator, catalog assistant, periodicals supervisor, reference assistant, etc. The following members of the support staff should not be included as paraprofessionals: secretaries, typists, bookkeepers, and others whose positions require primarily office-related skills; student library assistants, photographers, photocopy room and mailroom employees, audiovisual technicians, etc.; or professionals who may not hold a master's degree in librarianship, for example: systems analysts and other computer specialists, library business officers, library personnel officers, etc." 
33. For a survey of definitions of paraprofessionals see "Support Staff by Any Other Name," Library Mosaics 1:10-12 (Sept./Oct. 1989).

34. Criteria for Programs to Prepare Library/Media Technical Assistants (Chicago: American Library Association, 1979). The revised statement was adopted by the American Library Association Council on June 2, 1979.

35. The other elements of staff development that Miller considers important are participation in decision making, orientation programs, workshops and other in-house programs, formal and not-so-formal courses, and job swapping. See Rush G. Miller, "A Model for Support Staff Development in Academic Libraries," unpublished paper, 1988, p.4-5. Miller is dean of libraries, Bowling Green State University, Bowling Green, Ohio 43403-0175.

36. In my survey, the percentage of Carnegie classification respondents that use certain comparison criteria in the determination of paraprofessional salaries is: other campus support staff salaries, 83 percent; equivalent salaries at other institutions, 41 percent; librarians' salaries at the same institution, 14 percent; other government employees' salaries, 22 percent; and salaries established through collective bargaining negotiations, 24 percent.

37. Michael Gorman, "The Organization of Academic Libraries in the Light of Automation," in Advances in Library Automation and Networking," 1:158 (1987).

38. Michael Gorman, "The Academic Library in the Year 2001: Dream or Nightmare or Something in Between?" Journal of Academic Librarianship 17:8 (Mar. 1991).

39. Herbert S. White, "Professional Librarians and Professionals in Libraries," Library Journal 116:74 (Jan. 1991).

40. Mark E. Mentges, "Library Paraprofessionals in Academic Libraries-Where to Now?" Library Mosaics 2:15 (Mar./Apr. 1991).

41. A paraprofessional colleague from California wrote me after reading a typescript version of this article: "Not to be too critical of your concept of high-level librarianship, but from my observations here at ... and other libraries I have visited or have contacts at, I really feel that perhaps only $10-20 \%$ of the professionals are operating at the teaching and research level you envision. In looking at the overall picture, paraprofessionals might not be the group in doubt, but librarians may be the endangered species. The closing of Columbia's library school, and the real possibility of Berkeley's closing, send a chilling message. Certainly, to the campus administrations, library education seems to be expendable. Isn't this the fault of the profession for failing to be perceived as an integral part of scholarship? I am afraid the caretaker role too many librarians perform might be all too prevalent in academic settings ...."

42. Sheila S. Intner, "The Education of Copy Catalogers," Technicalities 11:6 (Mar. 1991).

43. Rush G. Miller, "Support Staff in Academic Libraries: The Dilemma and the Challenge," Journal of Educational Media and Library Science 25:364 (1988).

44. Melvil Dewey, "The Profession," American Library Journal 1:5 (Sept. 30, 1876). Dewey wrote that "the time has at last come when a librarian may, without assumption, speak of his occupation as a profession."

45. Pierce Butler, An Introduction to Library Science (Chicago: Univ. of Chicago Pr., 1933), pp.xi-xii.

46. An as yet unpublished national survey of the "status of academic status" conducted in 1990 by Charles B. Lowry, Larry R. Oberg, Irene B. Hoadley, and Rush G. Miller reveals that 67 percent of all academic libraries in the United States grant (some form of) faculty status to their librarians; 7 percent grant academic status; 24 percent grant professional/administrative status, and 2 percent impose civil service classifications.

47. Veaner, "Continuity or Discontinuity," p. 1-20.

48. Ibid., p.2. 